\title{
THE RIGHT OF RESTITUTION FOR CHILD VICTIMS OF SEXUAL VIOLENCE IN INDONESIA
}

\author{
Rosmalinda Rosmalinda* \\ Ningrum Natasya Sirait** \\ Suhaidi Suhaidi*** \\ Edy Ikhsan****
}

\begin{abstract}
Article 4 of the Convention on the Rights of the Child (CRC) mentions the obligations of state parties to implement the CRC. Furthermore, article 19 of the CRC requires State Parties to protect children from any form of violation including sexual violation through legislative, administrative, social and education measures. This article describes the results of research related to the implementation of CRC for child victims of sexual violence (CVSV) through court decisions. The analysis was conducted on seven Districts and three High Court decisions in 2018 in Medan and Deli Serdang Districts, North Sumatera Province in Indonesia concerning sexual violence which involve children as victims. The researcher conducted focus group discussions which involved two groups of respondents; (1) Law Enforcement Officers and (2) OPD (Organisasi Pemerintahan Daerah/Local Governments) and CSOs (Civil Society Organizations) which concerns CVSV issues. The finding shows that none of the court decisions mentioned about rights of the victims, as they focused only to punish the perpetrator(s). It is ironic since the right is regulated under several regulations in Indonesia concerning child protection. Therefore, the researcher recommends that police officers and Public Prosecutors should be more active in providing information concerning restitution for the victims. This will assist the victim(s) and his/her families to obtain justice not only by punishing the perpetrator but also by obtaining his/her right of restitution.
\end{abstract}

* Faculty of Law, North Sumatra University. Email: rosmalinda@usu.ac.id.

** Faculty of Law, Universitas Sumatra Utara. Email: nigrum.sirait@gmail.com.

*** Faculty of Law, Universitas Sumatra Utara. Email: suhaidi@usu.ac.id.

**** Faculty of Law, Universitas Sumatra Utara. Email: eikhsan@yahoo.com. 
Keywords: rights of sexual abuse victim(s), restitution rights for child victims, application of CRC.

\title{
KEPUTUSAN MAHKAMAH YANG BERKAITAN KEGANASAN SEKSUAL DIKALANGAN KANAK-KANAK DAN HAK GANTI RUGI UNTUK MANGSA DI INDONESIA
}

\begin{abstract}
ABSTRAK
Artikel 4 Konvensyen mengenai Hak Kanak-kanak telah mewajibkan negara-negara berpihak agar melaksanakan tanggungjawab mereka dibawah konvensyen tersebut. Tambahan pula, artikel 19 Konvensyen mewajibkan negara-negara ini agar melindungi kanak-kanak dari sebarang bentuk pelanggaran hak termasuk menghalang keganasan seksual melalui undanag-undang, kaedah pentadbiran serta melalui langkah-langkah sosial dan pendidikan. Makalah ini menerangkan dapatan kajian berkaitan pelaksanaan Konvensyen Hak Kanak-kanak pada mangsa keganasan seksual dikalangan kanak-kanak. Analisa telah dilakukan terhadap penghakiman dari 7 mahkamah daerah dan 3 mahkamah tinggi pada tahun 2018 di Medan dan daerah Deli Serdang, Provinsi Utara Sumatera, Indonesia. Penghakiman-penghakiman tersebut berkenaan jenayah keganasan seksual yang melibatkan mangsa kanak-kanak. Penyelidik telah melakukan perbincangan kumpulan terarah yang melibatkan 2 kumpulan responden. Kumpulan pertama melibatkan pegawai penguatkuasa dan 2 Organisasi Pemerintahan Daerah serta Organisasi Masyarakat Madani yang terlibat dalam menangani permasalahan kanak-kanak yang terlibat dengan keganasan seksual. Dapatan ini menunjukkan kebanyakan keputusan mahkamah hanya menyebut tentang hak mangsa, tetapi hanya memberikan hukuman terhadap penjenayah. Ianya suatu ironi kerana hak ini di kawal selia oleh peraturan berkenaan perlindungan kanak-2. Oleh itu, penyelidik menyarankan agar pegawai polis dan pendakwaraya sepatutnya lebih aktif dalam memberikan cadangan kepada mahkamah agar turut menganugerahkan pampasan untuk mangsa. Ini dapat membantu mangsa dan keluarga mereka bagi mendapatkan keadilan dan ini tidak dapat dicapai hanya dengan menghukum penjenayah.
\end{abstract}

Kata kunci: $\quad$ hak mangsa keganasan seksual, pampasan untuk mangsa penderaan seksual kanank-kanak, aplikasi Konvensyen Hak Kanak-Kanak. 


\section{INTRODUCTION}

Child abuse occurs in many countries around the world which unfortunately, includes Indonesia. There are many forms of abuse, involving physical and psychological assault, as well as sexual exploitation. As a gender-based violence, sexual exploitation may be attributed to some motivation, such as economic reasons. ${ }^{1}$ Furthermore, sexual exploitation occurs in variety background of communities. ${ }^{2}$ This can happen to anyone in any community in the world. ${ }^{3}$ The Convention on the Rights of the Child (CRC) is an international convention for the protection of boys and girls. Article 4 of the Convention discusses the general provisions for the implementation of the CRC through several steps for example legislative, administrative, and other measures. ${ }^{4}$ Other general provisions for the implementation of the CRC are mentioned in Article 42 on the obligation of the State to widely disclose the principles and provisions contained in the CRC and Article 44 Para.6 which requires the State to disseminate government reports on the implementation of the CRC to the wider community. Specifically, in the implementation of the CRC, it is stated in the CRC that the State party is obliged to ensure that the implementation of the CRC provisions based on the principle of non-discrimination as stated in article 2 and article 3(2), which states, the state party shall "...undertake to ensure the child such protection and care as is necessary for his or her wellbeing...".

In particular, the Committee on the Rights of the Child stipulates in Article 19, the protection of children from any form of violence. Some form of violence that occurs to a child, whether it be physical or

1 Olufunmilayo I. Fawole, 'Economic Violence to Women and Girls: Is It Receiving the Necessary Attention?', Trauma, Violence, and Abuse, 9.3 (2008), 167-77 <https://doi.org/10.1177/1524838008319255>.

2 Diana Bronson, 'Violence Against Women as a Human Rights Issue', Refuge: Canada's Journal on Refugees, 17.2 (1993), 14-15 <https://doi.org/10.25071/1920-7336.21737>.

3 Ibid.

4 Mervat Rishmawi, 2016, A Commentary on the United Nations Convention on the Rights of The Child, Article 4, The Nature of States Parties' Obligation, Martinus Nijhoff Publisher, Leiden. See also Besson, S. 2005, The Principle of Non-Discrimination in the Convention on the Rights of the Child. The International Journal of Children's Rights, 13(4), 433-461. 
psychological abuse, assault, neglect, injury or exploitation, as well as sexual abuse. ${ }^{5}$ Based on data collected by the Protection of Minors in the Church and contained in Pope Francis' official speech in Italy at the end of the summit "The Protection of Minors in the Church"6, citing several estimations issued by the United Nations Children's Fund (UNICEF). In 2014, UNICEF mentioned that more than 120 million girls were victims of violence in the world. This number represents the highest number of victims. ${ }^{7}$ This fact proves that the claim that girls are the main victims of human rights violations is justified. ${ }^{8}$

Several institutions noted the sexual violence that occurred in Indonesia in 2019. First, the Ministry of Women's Empowerment and Child Protection (Kementerian Pemberdayaan Perempuan dan Perlindungan Anak/KPPA) recorded that there were 1,500 reports of sexual violence against children. The data was recorded nationwide by KPPPA through its online information system from January 2019 to June 2019. ${ }^{9}$ Secondly, the Witness and Victim Protection Agency (Lembaga Perlindungan Saksi dan Korban or LPSK), has noticed an increase in the protection of sexual violence against children. Even this number exceeds other criminal acts, an increase in cases of sexual violence against children that occurred since 2016 is 25 cases. In 2017 there was an increase of 81 cases and the peak in 2018 with 206 cases. In June 2019, there had been 78 requests for cases of sexual violence against children. LPSK also said that 80.23 per cent of the perpetrators of sexual violence against children are people closest to them.

5 Australia Indonesia Partnership for Justice and MAPPI FH UI, 2016, Kekerasan Seksual di Indonesia: Data, Fakta, dan Realita. Jakarta.

6 Christopher Wells, "pope francis issues new legislation for protection of minors," Vatican News, accessed March 29, 2019, https://www.vaticannews.va/en/pope/news/2019-03/pope-francislegislation-protection-minors-vatiab.html.

7 Ibid

8 Australia Indonesia Partnership for Justice and MAPPI FH UI, 2016, Kekerasan Seksual di Indonesia: Data, Fakta, dan Realita. Jakarta.

9 Eva Safitri, "Kementerian PPPA Catat 1.500 Laporan Kekerasan Seksual Pada Anak," Detik News, accessed January 3, 2020, https://news.detik.com/berita/d-4694561/kementerian-pppa-catat-1500laporan-kekerasan-seksual-pada-anak. 
Meanwhile according to him, 19.77 percent was carried out by unknown people. ${ }^{10}$

According to this situation, the number of reported sexual violence is an iceberg phenomenon. ${ }^{11}$ This means that the number of victims shown in the report is less than the facts. This happens because many children who have suffered sexual violence do not accept and report their experiences of sexual violence for various reasons. Another factor why the number of sexual violence against children is smaller in the report than in actual fact is the difference in using the terminology by the State party either in its legislation or any kind of regulation concerning sexual violation. ${ }^{12}$ UNICEF, in the Implementation handbook for the CRC said that there are many countries which defined sexual abuse not only as violent sexual assaults but also other sexual activity, consensual or not, with children regarded as immature or below a certain defined age of sexual consent. ${ }^{13}$

Previously, Article 287 of the Sexual Criminal Code stipulated sexual consent for the rape of a child under 15 years of age, which stipulated: ${ }^{14}$

1. Anyone person who out of marriage has carnal knowledge of women whom he knows or reasonably should presume that she has not yet reached the age of fifteen years old, if it is not obvious from her age that she is not marriageable, shall be punished by a maximum imprisonment of nine years.

10 Matius Alfons, "LPSK: Kasus Kekerasan Seksual pada Anak Meningkat Tiap Tahun," Detik News, accessed January 3, 2020, https://news.detik.com/berita/d-4637744/lpsk-kasus-kekerasan-seksualpada-anak-meningkat-tiap-tahun.

11 Ibid.

12 PKWJ UI-MAGENTA LR\&A, Buku Saku; Mencegah dan Menangani Kekerasan Seksual terhadap Perempuan dan Anak di Lingkungan Pendidikan (Jakarta: PKWG, 2014): 20.

13 UNICEF, Implementation Handbook for the Convention on the Rights of the Child: Fully Revised Third Edition, 2007.

14 Directorate General of Law and Legislation, Ministry of Justice, Penal Code of Indonesia. 
2. Unless a woman is not yet twelve years old or there is one of Article 291 and Article 294, a lawsuit can only be brought by lawsuit.

Since the issuance of Law 35/2014 concerning Child Protection, Article 1 number 1 stated that the child, is someone who is not yet 18 (eighteen) years old, including children who are still in the womb. Meanwhile, what is meant by parents is the biological father and / or mother, or the father and / or step mother, or the father and / or number mother.

The increase in the age limit of children which may give sexual consent in Indonesia can be said to be the achievement of the implementation of CRC in Indonesia. This is based on the reliance of a child's age limit that is in accordance with the age limit set according to Article 1 of the CRC. Indonesia's achievement in increasing the age of children for sexual consent happened in 2019. At that time, Indonesian government legalized Law Number 16 of 2019 concerning Amendments to Law 1 of 1974 concerning Marriage. The amendment to this law is a follow up to the decision of the Constitutional Court of the Republic of Indonesia which has issued Decision of the Constitutional Court Number 22 / PUU-XV / 2017. One of the considerations of the Constitutional Court in the ruling is the impact of marriage for children which there is difference in treatment between men and women. This condition affects the fulfilment of the basic rights or constitutional rights of citizens, both those belonging to the group of civil and political rights and economic rights, educational, social and cultural rights. Furthermore, Indonesian government should commit in protecting the rights in accordance with the Non-Discrimination principle as stated in the CRC.

The changes to the norms in Law Number 1 of 1974 saw the minimum age for marriage for women raised to the same minimum age for marriage for men, which is 19 (nineteen) years old. Furthermore, this change shows the seriousness of the Indonesian government to ensure the implementation of the CRC which is based on the principle of Non-Discrimination and in accordance with the child's growth and development as required by the CRC. The definition of sexual abuse and exploitation of the Committee on the Rights of the Child includes not only conduct involving violence or other forms of coercion, but also all sexual conduct with a child below a certain age, even when the 
perpetrator and the child was or appeared to be in "a relationship". ${ }^{15}$ Consequently sexual intercourse with a child below the age of consent renders the perpetrator automatically liable to the charge of rape. The Committee on the Rights of the Child has emphasized the importance of setting a minimum age below which a child's consent is not considered to be valid. In its General Comment No. 4 on "Adolescent health and development in the context of the Convention on the Rights of the Child", the Committee refers to the need to set a minimum age for sexual consent and marriage.

Issues related to the implementation of the provisions of the Convention on the Rights of the Child related to Indonesia's effective age of sexual consent and facts related to the age at which children began to actively engage in sexual activities. The results of a study conducted by the Adolescent Reproductive Health Survey (SKRR) cited in a case study It shows that the age of the first date for Indonesian teenagers is 12 years old. Sexual behaviour that has been done during dating is holding hands (88\%), lip kissing (32\%), stimulating or feeling $(11 \%)$, having sexual relations with young women (2\%), having sexual relations with young men (5\%) ), and $10 \%$ of these sexual relationships are with friends and commercial sex workers. ${ }^{16}$ Information about adolescent sexual behaviour in Indonesia in the context of protecting victims of sexual violence has a legal impact on perpetrators. ${ }^{17}$ If there are two cases of sexual violation on children, the perpetrators could be have different treatment or punishment either the kind or the period of punishment related to the fact concerning sexual consent and minor sexual behaviour of children.

Based on the above description, this article will answer the research questions on how to implement the Convention on the Rights of the Child, especially Article 34, to protect children (including victims of sexual abuse) in the Indonesian criminal justice system.

15 Ben Mathews and Delphine Collin-Vézina, 'Child Sexual Abuse: Toward a Conceptual Model and Definition', Trauma, Violence, and Abuse, 20.2 (2019), 131-48 <https://doi.org/10.1177/1524838017738726>.

16 Ibid.

17 PKWJ UI-MAGENTA LR\&A, Buku Saku; Mencegah dan Menangani Kekerasan Seksual terhadap Perempuan dan Anak di Lingkungan Pendidikan (Jakarta: PKWG, 2014): 27. 


\section{RESEARCH METHODOLOGY}

This research provides a textual analysis of the relevant articles in the Convention on the Rights of the Child that relate to the right to restitution for children who are victims of sexual violence. This would entail a detailed look into Article 4, Article 19 and Article 34 of the Convention on the Rights of the Child.

Particular attention is given to Article 34 (a) of CRC which was adopted in Indonesian Law concerning Child Protection through 10 court decisions, seven District and three High Court decisions in Medan and Lubuk Pakam, North Sumatera Province, Indonesia from January to December 2018. These cases concerning sexual violence which involves children are analysed. Furthermore, the study also conducted Focus Group Discussions (FGDs) in Medan which involved two groups of respondents from Medan City and Deli Serdang District. The first group were (1) Law Enforcers and Local Government Organizations and the second group (2) Civil Society Organisations (CSO). The FGDs are conducted to look at the perspectives of those who were in charge of applying the law as laid down in the decisions.

\section{RESULT AND DISCUSSION}

In general, sexual violence against children is a violation of human rights. Violation refers to the right of a State party to fulfil or perform its obligations in the International Human Rights Covenant and other international human rights law instruments. When a State party fails to fulfil its obligations under the treaty, it means that the State has violated the human rights owed to its citizens. There is a long history on Child's rights. Internationally, it has been discussed long ago by the international community through the declaration of children's rights. On November 20, 1989, the United Nations adopted the "Convention on the Rights of the Child" with Resolution 44/25. Today, the Convention on the Rights of the Child has become an international legal instrument that can achieve its goals in providing children's rights.

State obligations to fulfil child victims' rights of sexual violence are regulated in the CRC. Article 4 states the general obligations. This Article mentions that the state parties have the obligation to fulfil child rights by taking appropriate legislative, administrative and other measures to ensure implementation of the rights recognized in the CRC. 
In order to specifically regulate any form of abuse against children, Article 19 and Article 34 focuses on the State obligation to protect children from sexual violence. This article clearly mentions:

States Parties shall take all appropriate legislative, administrative, social and educational measures to protect the child from all forms of physical or mental violence, injury or abuse, neglect or negligent treatment, maltreatment or exploitation, including sexual abuse, while in the care of parent(s), legal guardian(s) or any other person who has the care of the child.

For this purpose, State parties must take appropriate bilateral and multilateral steps to prevent the following:

(a) the inducement or coercing a child to engage in any unlawful sexual activity;

(b) the exploitative use of children in prostitution or other unlawful sexual practices;

(c) the exploitative use of children in pornographic performances and materials.

In order to comply with Article 34 of the CRC regarding the government's efforts to protect children who are victims of sexual violence, Indonesia has made arrangements regarding sexual violence and exploitation, namely through the promulgation of the following laws:

(1) Law No. 23 of 2002 concerning Child Protection.

(2) Law No. 35 of 2014 concerning amendments to Law No. 23 of 2002 concerning Child Protection; and

(3) Law No. 17 of 2016 concerning Establishment of substitute government regulations number 1 of 2016 concerning Second Amendment to Law number 23 of 2002 concerning Child Protection. Legal arrangements regarding the protection of sexual violence against children will certainly have a positive impact on children's development.

In fact, as mentioned earlier, in Indonesia, adolescents under the age of 18 engage in various forms of sexual activity, including sexual 
intercourse with a risk of pregnancy. ${ }^{18}$ This fact has implications for law enforcement in Indonesia, which allows children to become victims and perpetrators of sexual violence at the same time. Research to study children's involvement in sexual violence states that some of the factors that children commit rape are because they often watch pornographic videos, and the lack of supervision from parents. ${ }^{19}$ In addition to the factors that cause children to be the perpetrators of sexual violence cases, the focus of this research is to realize the rights of children who are victims of sexual violence. This study examines 7 District and 3 High Court decisions in 2018 on sexual violence which involve Children as the victim and perpetrator. All decisions are legally binding, 3 at the District Court level while 3 at the High Court level.

Table 1. List of Court Decisions in 2018

\begin{tabular}{|l|l|l|}
\hline No & $\begin{array}{l}\text { Number of District Court } \\
\text { Decisions (Medan and } \\
\text { Lubuk Pakam) }\end{array}$ & $\begin{array}{c}\text { Number of Provincial Court } \\
\text { Decision (Medan) }\end{array}$ \\
\hline 1 & $\begin{array}{l}\text { Court Decisions No 86/Pid. } \\
\text { Sus-Anak/2018/PN Lbp }\end{array}$ & \\
\hline 2 & $\begin{array}{l}\text { Court Decisions 71/ Pid. } \\
\text { Sus-Anak/2018/ PN Lbp }\end{array}$ & $\begin{array}{l}\text { Court Decisions No 52/Pid. } \\
\text { Sus-anak/2018/ PN Lbp }\end{array}$ \\
\hline 4 & $\begin{array}{l}\text { Court Decisions No 37 } \\
\text { /Pid.Sus -Anak/ } \\
\text { 2018/PN.Medan }\end{array}$ & $\begin{array}{l}\text { Court Decisions No 22/ } \\
\text { Pid.Sus-Anak/ 2018/PT.MDN }\end{array}$ \\
\hline 5 & $\begin{array}{l}\text { Court Decisions No } \\
\text { 49/Pid.Sus- } \\
\text { Anak/2018/PN.Mdn }\end{array}$ & $\begin{array}{l}\text { Court Decisions No 30/ } \\
\text { Pid.sus-Anak/ 2018/ PT MDN }\end{array}$ \\
\hline
\end{tabular}

18 Nita Istiqomah and Hari Basuki Notobroto, "Pengaruh Pengetahuan, Kontrol Diri Terhadap Perilaku Seksual Pranikah Di Kalangan Remaja SMK Di Surabaya," Jurnal Biometrika Dan Kependudukan, 5.2 (2017), 125 <https://doi.org/10.20473/jbk.v5i2.2016.125-134>.

19 Valentino Yohanes, "Pemerkosaan Antara Pelajar Di Kabupaten Sintang Di Tinjau Dari Sudut Kriminolog I," Jurnal Hukum Prodi Ilmu Hukum Fakultas Hukum Untan (Jurnal Mahasiswa S1 Fakultas Hukum) Universitas Tanjungpura, 5.1. (2016). 


\begin{tabular}{|l|l|l|}
\hline No & $\begin{array}{l}\text { Number of District Court } \\
\text { Decisions (Medan and } \\
\text { Lubuk Pakam) }\end{array}$ & $\begin{array}{c}\text { Number of Provincial Court } \\
\text { Decision (Medan) }\end{array}$ \\
\hline 6 & $\begin{array}{l}\text { Court Decisions No 52/ } \\
\text { Pid.Sus-Anak/ 2018/PN } \\
\text { MDN }\end{array}$ & $\begin{array}{l}\text { Court Decisions No 29/ Pid. } \\
\text { Sus-Anak/2018/ PT MDN }\end{array}$ \\
\hline 7 & $\begin{array}{l}\text { Court Decisions No 30/ } \\
\text { Pid.Sus-Anak/2018/PN Mdn }\end{array}$ \\
\hline
\end{tabular}

\section{Regulation against sexual behaviour}

Important matters relating to the use of the terms used in Article 34 include the inducement or coercion of children to engage in any illegal sexual activity. The table below shows the terms of sexual violence used in the CRC with additional explanations provided by the CRC Committee. ${ }^{20}$ Unfortunately, there is only a general comment on Article 19 but not on Article 34 of the CRC. All terms used in the CRC must be considered as legal terms relating to sexual violence on children.

Table 2: Terminology used in CRC and The Explanations

\begin{tabular}{|l|l|}
\hline \multicolumn{1}{|c|}{ Article 19 } & \multicolumn{1}{c|}{ Article 34 } \\
\hline $\begin{array}{l}\text { CRC } \\
\text { Gexual abuse }\end{array}$ & $\begin{array}{l}\text { CRC } \\
\text { Sexual abuse \& sexual } \\
\text { exploitation }\end{array}$ \\
$\begin{array}{l}\text { Add an explanation of the } \\
\text { concept of Sexual Harassment } \\
\text { and Exploitation. Sexual } \\
\text { harassment and exploitation: } \\
\begin{array}{l}\text { a) Encouragement or coercion } \\
\text { of a child to engage in } \\
\text { unlawful or psychologically } \\
\text { dangerous sexual activities; }\end{array}\end{array}$ & $\begin{array}{l}\text { ancouragement or coercion } \\
\text { of a child to engage in } \\
\text { unlawful sexual activity; }\end{array}$ \\
b) $\begin{array}{l}\text { The exploitative use of } \\
\text { children in prostitution or } \\
\text { other unlawful sexual } \\
\text { practices; }\end{array}$
\end{tabular}

20 A. D. Tiuliandin, For the Protection of Children (Luxembourg: Meditsinskaia Sestra, 1979). 


\begin{tabular}{|l|l|}
\hline \multicolumn{1}{|c|}{ Article 19 } & \multicolumn{1}{|c|}{ Article 34 } \\
\hline b) $\begin{array}{l}\text { Use of children in } \\
\text { commercial sexual } \\
\text { exploitation; and; }\end{array}$ & c) $\begin{array}{l}\text { The exploitative use of } \\
\text { children in pornographic } \\
\text { performances and material }\end{array}$ \\
c) $\begin{array}{l}\text { The use of children in audio } \\
\text { or visual images of child } \\
\text { sexual abuse; }\end{array}$ & \\
d) $\begin{array}{l}\text { Child prostitution, sexual } \\
\text { slavery, Sexual Exploitation } \\
\text { in travel and tourism, human } \\
\text { trafficking (within and } \\
\text { between countries) and the } \\
\text { sale of children for sexual } \\
\text { purposes and forced } \\
\text { marriages. Many children } \\
\text { experience sexual } \\
\text { victimization which is not } \\
\text { accompanied by physical } \\
\text { strength or restraint but } \\
\text { which is psychologically } \\
\text { disruptive, exploitative and } \\
\text { traumatic. }\end{array}$ \\
\hline
\end{tabular}

The scope of the term "sexual violence against children" stipulated in the CRC is related to the sexual behaviour of young adolescents, and the scope of application in Indonesia will be different. This consequence is seen through the court decision analysed where in the court's decisions the panel of judges decide on the case using the provisions of the Criminal Code and the Child Protection Act. In the previous paragraph, it stated that there is a Law concerning Child protection. The law was amended twice. The latest amendment is Law No. 17 of 2016 concerning Establishment of substitute government regulations number 1 of 2016 concerning Second Amendment to Law number 23 of 2002 concerning Child Protection. 
Table 3: District Court Decisions of PN Medan, PN Lubuk Pakam and Provincial Court Decision of Medan

\begin{tabular}{|c|c|c|c|c|}
\hline No & $\begin{array}{c}\text { Description } \\
\text { and Date of } \\
\text { court } \\
\text { Decision }\end{array}$ & $\begin{array}{l}\text { Perpetrator } \\
\text { and Victim }\end{array}$ & Norms & Court Decision(s) \\
\hline 1 & $\begin{array}{l}\text { Decision } \\
\text { No. } 86 \text { / } \\
\text { Pid. Sus- } \\
\text { Anak / } \\
2018 \text { / PN } \\
\text { Lbp } \\
\\
\text { Severed on } \\
\text { November } \\
26,2018\end{array}$ & $\begin{array}{l}\text { Perpetrators; } \\
\text { DI, 15 } \\
\text { years, } 2 \\
\text { December } \\
2002 \\
\text { Victim; } \\
\text { DSS, 14 } \\
\text { years old }\end{array}$ & $\begin{array}{l}\text { Article } 81 \\
\text { paragraph } \\
\text { (2) of RI } \\
\text { Law No. } 35 \\
\text { of } 2014 \\
\text { concerning } \\
\text { amendments } \\
\text { to RI Law } \\
\text { No. } 23 \text { of } \\
2002 \\
\text { concerning } \\
\text { Child } \\
\text { protection, } \\
\text { Law No. } 11 \\
\text { of } 2012 \\
\text { concerning } \\
\text { the juvenile } \\
\text { justice } \\
\text { system and } \\
\text { Law Number } \\
8 \text { of } 1981 \\
\text { concerning } \\
\text { Criminal } \\
\text { Procedure } \\
\text { Law }\end{array}$ & $\begin{array}{l}\text { 1. Stating the Actor } \\
\text { has been proven } \\
\text { legally and } \\
\text { convincingly } \\
\text { guilty of a crime } \\
\text { "intentionally } \\
\text { persuading a } \\
\text { child to have } \\
\text { intercourse with } \\
\text { him", as in the } \\
\text { Primary } \\
\text { indictment; } \\
\text { Imposing a crime } \\
\text { to the perpetrators } \\
\text { with } \\
\text { imprisonment for } \\
4 \text { (four) years and } \\
\text { training for } 2 \\
\text { (two) months; } \\
\text { Establish the } \\
\text { period of arrest } \\
\text { and detention that } \\
\text { has been handed } \\
\text { down to the } \\
\text { perpetrators } \\
\text { deducted fully } \\
\text { from the criminal } \\
\text { sentence } \\
\text { imposed; } \\
\text { Establish } \\
\text { evidence in the } \\
\text { form of } 1 \text { (one } \\
\text { red negligee skirt, } \\
1 \text { (one) BH, } 1 \\
\text { (one) piece of } \\
\text { underwear } \\
\text { 3. }\end{array}$ \\
\hline
\end{tabular}




\begin{tabular}{|c|c|c|c|c|}
\hline & & & & $\begin{array}{l}\text { returned to the } \\
\text { rightful; } \\
\text { 5. Establish the } \\
\text { perpetrators } \\
\text { remain in } \\
\text { custody; } \\
\text { 6. Charge the } \\
\text { principal to pay } \\
\text { the court fee in } \\
\text { the amount of } \\
\text { IDR. 2,000 (two } \\
\text { thousand rupiah). }\end{array}$ \\
\hline 2 & $\begin{array}{l}\text { Decision } \\
\text { Number } 71 \\
\text { / Pid. Sus- } \\
\text { Anak / } \\
2018 \text { / PN } \\
\text { Lbp } \\
\text { It was } \\
\text { decided on } \\
\text { September } \\
\text { 19, 2018 }\end{array}$ & $\begin{array}{l}\text { Perpetrator: } \\
\text { R; } 15 \text { years; } \\
\text { July 9, } 2003 \\
\text { Victim: N, } \\
15 \text { years } \\
\text { old, July 25, } \\
2003\end{array}$ & $\begin{array}{l}\text { Article } 81 \\
\text { Paragraph } \\
\text { (2) of RI } \\
\text { Law No. } 35 \\
\text { of } 2014 \\
\text { concerning } \\
\text { amendments } \\
\text { to RI Law } \\
\text { No. } 23 \text { of } \\
2002 \\
\text { concerning } \\
\text { the } \\
\text { protection of } \\
\text { children, and } \\
\text { Law No. } 8 \text { of } \\
\text { 1981 } \\
\text { concerning } \\
\text { criminal } \\
\text { proceedings } \\
\text { and other } \\
\text { relevant laws } \\
\text { and } \\
\text { regulations }\end{array}$ & $\begin{array}{l}\text { 1. Stating the Actor } \\
\text { has been proven } \\
\text { legally and } \\
\text { convincingly } \\
\text { guilty of a crime } \\
\text { "intentionally } \\
\text { persuading a } \\
\text { child to have } \\
\text { intercourse with } \\
\text { him", as in the } \\
\text { primary } \\
\text { indictment; } \\
\text { Imposing a crime } \\
\text { to the perpetrators } \\
\text { with } \\
\text { imprisonment for } \\
2 \text { (two) years and } \\
\text { job training for } 3 \\
\text { (three) months; } \\
\text { Establish the } \\
\text { period of arrest } \\
\text { and detention that } \\
\text { has been handed } \\
\text { down to the } \\
\text { perpetrators } \\
\text { deducted fully } \\
\text { from the criminal }\end{array}$ \\
\hline
\end{tabular}




\begin{tabular}{|c|c|c|c|c|}
\hline & & & & $\begin{array}{l}\text { sentence } \\
\text { imposed; } \\
\text { 4. } \begin{array}{l}\text { Establish the } \\
\text { perpetrators } \\
\text { remain in } \\
\text { custody; }\end{array} \\
\text { 5. Determine the } \\
\text { perpetrators in } \\
\text { carrying out the } \\
\text { crime placed in } \\
\text { the Institute for } \\
\text { Special } \\
\text { Development of } \\
\text { Children (LPKA) } \\
\text { Class I Medan; } \\
\text { Imposing on the } \\
\text { perpetrators to } \\
\text { pay the court fee } \\
\text { in the amount of } \\
\text { IDR 2,000 (two } \\
\text { thousand rupiah). }\end{array}$ \\
\hline 3 & $\begin{array}{l}\text { Court } \\
\text { Decision } \\
\text { No. 52 / } \\
\text { Pid. Sus- } \\
\text { anak / 2018 } \\
\text { / PN Lbp } \\
\text { It was } \\
\text { decided on } \\
\text { July 19, } \\
\text { 2018 } \\
\text { Perpetrators } \\
\text { and victims } \\
\text { in dating } \\
\text { status that } \\
\text { began on } \\
\text { May } 7 \text {, } \\
\text { 2018; }\end{array}$ & $\begin{array}{l}\text { Actors: HD } \\
\text { als A als J; } \\
17 \text { years } 11 \\
\text { months; } \\
\text { July 11, } \\
2000 \\
\text { Victim; RE; } \\
15 \text { years }\end{array}$ & $\begin{array}{l}\text { Article } 81 \\
\text { paragraph } \\
\text { (2) of RI } \\
\text { Law No. } 35 \\
\text { of } 2014 \\
\text { concerning } \\
\text { amendments } \\
\text { to RI Law } \\
\text { No. } 23 \text { of } \\
\text { 2002 } \\
\text { concerning } \\
\text { Child } \\
\text { protection, } \\
\text { and Law No. } \\
8 \text { of } 1981 \\
\text { concerning } \\
\text { criminal } \\
\text { procedural } \\
\text { law and } \\
\text { other }\end{array}$ & 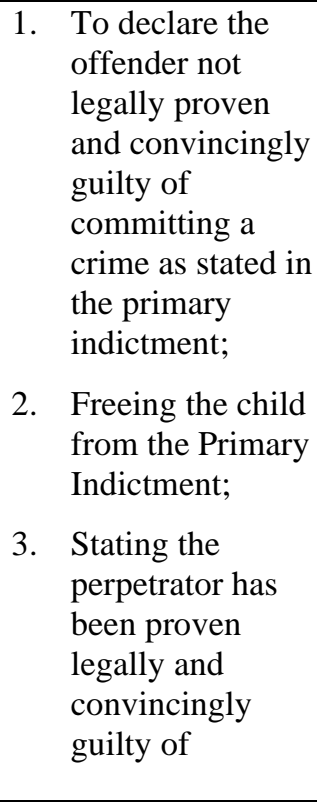 \\
\hline
\end{tabular}




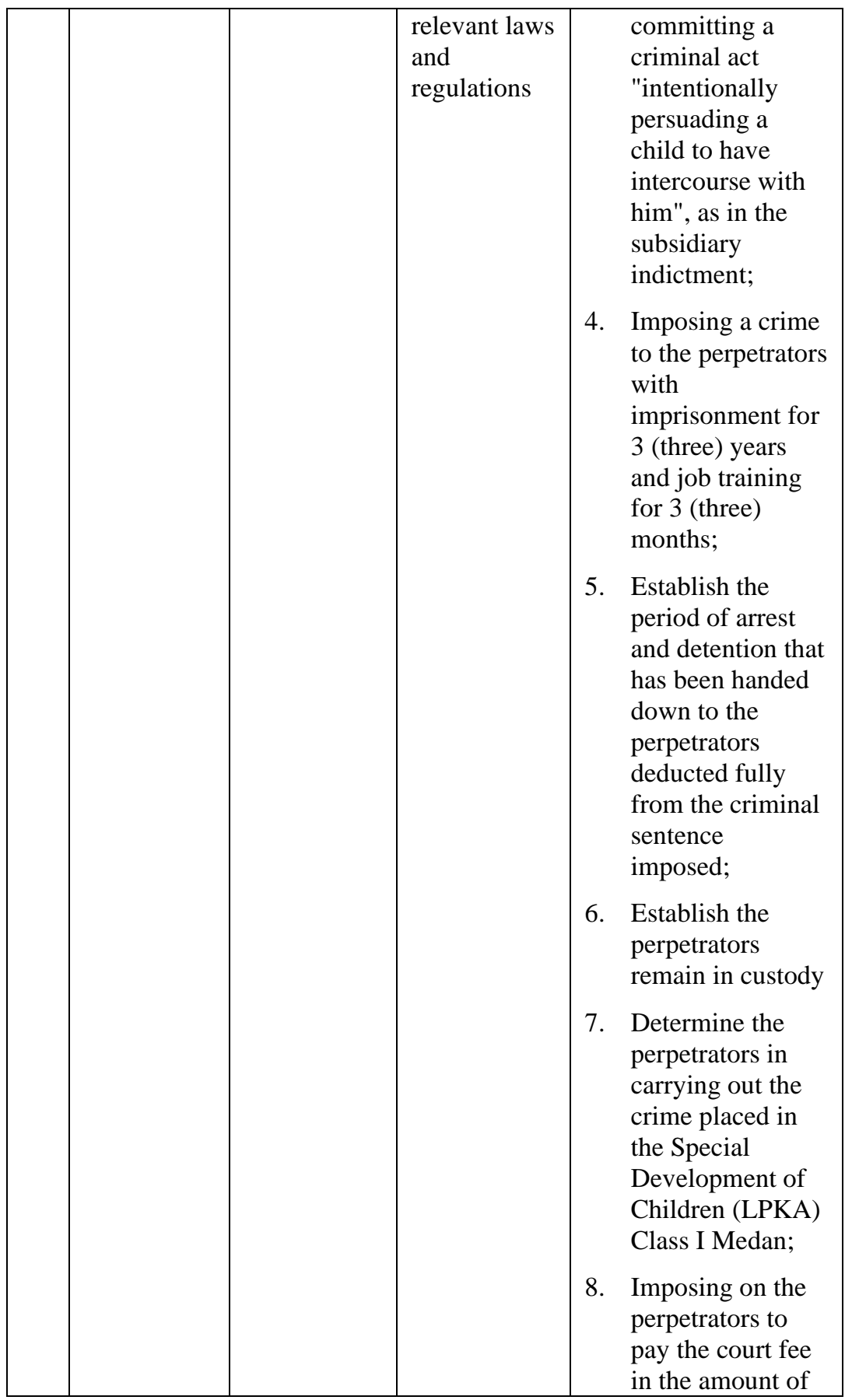




\begin{tabular}{|c|c|c|c|c|c|}
\hline & & & & & $\begin{array}{l}\text { IDR 2,000 (two } \\
\text { thousand rupiah). }\end{array}$ \\
\hline 4 & $\begin{array}{l}\text { Court } \\
\text { Decision } \\
\text { Number } 30 \\
\text { / Pid.Sus- } \\
\text { Anak / } \\
2018 \text { / PN } \\
\text { Mdn; was } \\
\text { terminated } \\
\text { on April } \\
\text { 19, } 2018\end{array}$ & $\begin{array}{l}\text { Perpetrator: } \\
\text { SRS; } 15 \\
\text { years / } 30 \\
\text { September } \\
2002 \\
\text { Victim: } \\
\text { TMS; } 15 \\
\text { Years } 11 \\
\text { Months }\end{array}$ & $\begin{array}{l}\text { Article } 81 \\
\text { paragraph } \\
\text { (1) of Law } \\
\text { No. } 23 \text { of } \\
2002 \\
\text { concerning } \\
\text { the } \\
\text { Protection of } \\
\text { Children Jo. } \\
\text { Article } 76 \text { D } \\
\text { RI Law No. } \\
35 \text { of } 2014 \\
\text { concerning } \\
\text { amendments } \\
\text { to RI Law } \\
\text { No. } 23 \text { of } \\
2002 \\
\text { concerning } \\
\text { Child } \\
\text { Protection } \\
\text { and relevant } \\
\text { legal } \\
\text { provisions }\end{array}$ & 1. & $\begin{array}{l}\text { Stating that the } \\
\text { offender has been } \\
\text { legally proven } \\
\text { and convincingly } \\
\text { guilty of } \\
\text { committing a } \\
\text { crime } \\
\text { "intentionally } \\
\text { threatening } \\
\text { violence, forcing } \\
\text { the child to have } \\
\text { intercourse with } \\
\text { him"; } \\
\text { Convicting a } \\
\text { criminal against } \\
\text { an offender, } \\
\text { therefore, } \\
\text { imprisonment for: } \\
3 \text { (three) years, } \\
\text { and job training } \\
\text { for } 6 \text { (six) } \\
\text { months; } \\
\text { Determine the } \\
\text { period of } \\
\text { detention that has } \\
\text { been served by } \\
\text { the perpetrators } \\
\text { deducted entirely } \\
\text { from the criminal } \\
\text { sentenced; } \\
\text { Ordering that the } \\
\text { perpetrators of } \\
\text { children are } \\
\text { arrested; } \\
\text { Charging } \\
\text { offenders to pay a } \\
\text { case fee of IDR } \\
2,000,- \text { (two } \\
\text { thousand rupiah). }\end{array}$ \\
\hline
\end{tabular}




\begin{tabular}{|c|c|c|c|c|}
\hline 5 & $\begin{array}{l}\text { Court } \\
\text { Decision } \\
\text { No. } 37 \\
\text { /Pid.Sus - } \\
\text { Anak / } \\
\text { 2018 / } \\
\text { PN.Medan } \\
\\
\text { Severed on } \\
\text { June 5, } \\
2018\end{array}$ & $\begin{array}{l}\text { Perpetrator: } \\
\text { SH als PH, } \\
17 \text { years } 11 \\
\text { Month / } 10 \\
\text { June } 2000 \\
\text { Victim; } \\
\text { IWS, not } \\
\text { mentioned } \\
\text { age, high } \\
\text { school } \\
\text { student }\end{array}$ & $\begin{array}{l}\text { Article } 81 \\
\text { paragraph } \\
\text { (2) of the } \\
\text { Law of the } \\
\text { Republic of } \\
\text { Indonesia } \\
\text { Number } 35 \\
\text { of } 2014 \\
\text { concerning } \\
\text { Amendments } \\
\text { to the Law } \\
\text { of the } \\
\text { Republic of } \\
\text { Indonesia } \\
\text { Number } 23 \\
\text { of } 2002 \\
\text { concerning } \\
\text { Protection of } \\
\text { Children and } \\
\text { the Law of } \\
\text { the Republic } \\
\text { of Indonesia } \\
\text { Number } 8 \text { of } \\
\text { 1931, } \\
\text { concerning } \\
\text { Criminal } \\
\text { Procedure } \\
\text { and other } \\
\text { relevant laws }\end{array}$ & $\begin{array}{l}\text { 1. Declares that the } \\
\text { offender has been } \\
\text { proven legally } \\
\text { and convincingly } \\
\text { guilty of } \\
\text { committing a } \\
\text { crime } \\
\text { "deliberately } \\
\text { persuading a } \\
\text { child to have } \\
\text { intercourse with a } \\
\text { child" as the } \\
\text { Second charge; } \\
\text { Convicted a } \\
\text { crime against a } \\
\text { child with } \\
\text { criminal guiding } \\
\text { in the Foundation } \\
\text { of National } \\
\text { Inspiration } \\
\text { Foundation at } \\
\text { Jalan Surya } \\
\text { Komplek Blok I } \\
\text { No. } 40 \text {, } \\
\text { Environment I, } \\
\text { East Helvetia } \\
\text { Village, for } 2 \\
\text { (two) years; } \\
\text { children are } \\
\text { burdened with the } \\
\text { Determine the } \\
\text { period of arrest } \\
\text { child be expelled } \\
\text { immediately; } \\
\text { experienced by } \\
\text { the child } \\
\text { deducted entirely } \\
\text { from the criminal } \\
\text { sentence; } \\
\text { Order that the } \\
\text { 5. }\end{array}$ \\
\hline
\end{tabular}




\begin{tabular}{|c|c|c|c|c|c|}
\hline & & & & & $\begin{array}{l}\text { cost of the case in } \\
\text { the amount of } \\
\text { IDR 5,000 (five } \\
\text { thousand rupiah). }\end{array}$ \\
\hline 6 & $\begin{array}{l}\text { Court } \\
\text { Decision } \\
\text { Number } 49 \\
\text { / Pid.Sus- } \\
\text { Anak / } \\
2018 \text { / } \\
\text { PN.Mdn } \\
\text { Terminated } \\
\text { on August } \\
\text { 20, 2018 }\end{array}$ & $\begin{array}{l}\text { Perpetrator: } \\
\text { FS als FM; } \\
15 / 19 \\
\text { February } \\
2003 \\
\text { Victim: DK, }\end{array}$ & $\begin{array}{l}\text { Article } 332 \\
\text { paragraph } \\
\text { (1) of the } \\
\text { Indonesian } \\
\text { Criminal } \\
\text { Code Jo Law } \\
\text { RI No. } 11 \text { of } \\
2012 \\
\text { concerning } \\
\text { the system of } \\
\text { juvenile } \\
\text { justice, and } \\
\text { the } \\
\text { provisions of } \\
\text { the law } \\
\text { concerned }\end{array}$ & 1. & $\begin{array}{l}\text { Stating the } \\
\text { perpetrator has } \\
\text { been proven } \\
\text { legally and } \\
\text { convincingly } \\
\text { guilty of } \\
\text { committing a } \\
\text { crime "Bringing } \\
\text { away a woman } \\
\text { who is not yet } \\
\text { mature without } \\
\text { the will of her } \\
\text { parents or } \\
\text { guardians but } \\
\text { only with her } \\
\text { consent with a } \\
\text { view to her } \\
\text { mastery outside } \\
\text { of marriage"; } \\
\text { Dropping the } \\
\text { penalty with the } \\
\text { perpetrators with } \\
\text { imprisonment for } \\
2 \text { (two) years; } \\
\text { Determine the } \\
\text { period of } \\
\text { detention that has } \\
\text { been served by } \\
\text { the perpetrator is } \\
\text { summarized } \\
\text { entirely from the } \\
\text { criminal sentence } \\
\text { imposed; } \\
\text { Determine the } \\
\text { perpetrators are in } \\
\text { custody; } \\
\text { Imposing the } \\
\text { Actor to pay a }\end{array}$ \\
\hline
\end{tabular}




\begin{tabular}{|c|c|c|c|c|c|}
\hline & & & & & $\begin{array}{l}\text { case of IDR 2,000 } \\
\text { (two thousand } \\
\text { rupiah). }\end{array}$ \\
\hline 7 & $\begin{array}{l}\text { Decision } \\
\text { Number } 52 \\
\text { / Pid.Sus- } \\
\text { Anak / } \\
2018 \text { / PN } \\
\text { MDN } \\
\text { Severed on } \\
\text { August 23, } \\
2018 \\
\text { Mention } \\
\text { that the best } \\
\text { interests of } \\
\text { the child } \\
\text { above any } \\
\text { interest }\end{array}$ & $\begin{array}{l}\text { Perpetrator: } \\
\text { DDPPM, } 17 \\
\text { Years 09 } \\
\text { Month / } 5 \\
\text { November } \\
2000 \\
\text { Victim; } \\
\text { USA, 13 } \\
\text { Years 09 } \\
\text { Month / } 8 \\
\text { May 2003, } \\
\text { grade IX } \\
\text { junior high } \\
\text { school }\end{array}$ & $\begin{array}{l}\text { Article } 82 \\
\text { paragraph } \\
\text { (1) jo. } \\
\text { Article 76E } \\
\text { Law of the } \\
\text { Republic of } \\
\text { Indonesia } \\
\text { Number } 35 \\
\text { of } 2014 \\
\text { concerning } \\
\text { Amendments } \\
\text { to the Law } \\
\text { of the } \\
\text { Republic of } \\
\text { Indonesia } \\
\text { Number } 23 \\
\text { of } 2002 \\
\text { concerning } \\
\text { Child } \\
\text { Protection }\end{array}$ & 1. & $\begin{array}{l}\text { Declares the } \\
\text { offender proven } \\
\text { legally and } \\
\text { convincingly } \\
\text { guilty of } \\
\text { committing a } \\
\text { crime by } \\
\text { deliberately } \\
\text { persuading a } \\
\text { child to commit } \\
\text { obscene acts; } \\
\text { Imposing a crime } \\
\text { to the perpetrators } \\
\text { with } \\
\text { imprisonment for } \\
6 \text { (six) years and } \\
\text { work training for } \\
3 \text { (three) months } \\
\text { in the assignment } \\
\text { of BAPAS; } \\
\text { Establish a period } \\
\text { of arrest and } \\
\text { detention that has } \\
\text { been lived by } \\
\text { children deducted } \\
\text { entirely from the } \\
\text { criminal } \\
\text { sentence; } \\
\text { To keep the child } \\
\text { in custody; } \\
\text { Imposing the } \\
\text { perpetrator to pay } \\
\text { a court fee in the } \\
\text { amount of IDR } \\
5,000 \text { (five } \\
\text { thousand rupiah). }\end{array}$ \\
\hline 8 & $\begin{array}{l}\text { Decision } \\
\text { Number } 22\end{array}$ & $\begin{array}{l}\text { Perpetrator: } \\
\text { SH als PH, }\end{array}$ & & & $\begin{array}{l}\text { Receive an appeal } \\
\text { request from the }\end{array}$ \\
\hline
\end{tabular}




\begin{tabular}{|c|c|c|c|c|c|}
\hline & $\begin{array}{l}\text { / Pid.Sus- } \\
\text { Anak / } \\
\text { 2018 / } \\
\text { PT.MDN } \\
\\
\text { Severed on } \\
\text { July 24, } \\
2018\end{array}$ & $\begin{array}{l}17 \text { years } 11 \\
\text { Month / } 10 \\
\text { June } 2000 \\
\text { Victim; } \\
\text { IWS, not } \\
\text { mentioned } \\
\text { age, high } \\
\text { school } \\
\text { student }\end{array}$ & & 2. & $\begin{array}{l}\text { Public } \\
\text { Prosecutor; } \\
\text { Strengthening the } \\
\text { decision of the } \\
\text { Medan District } \\
\text { Court on 5 June } \\
\text { 2018 Number } 37 \\
\text { / Pid.Sus-Anak / } \\
\text { 2018 / PN.Mdn, } \\
\text { to which the } \\
\text { appeal was } \\
\text { requested; } \\
\text { Charging children } \\
\text { to pay court fees } \\
\text { at the two levels } \\
\text { of the Court } \\
\text { which in the } \\
\text { appeal level of } \\
\text { IDR 2,000 (two } \\
\text { thousand rupiah). }\end{array}$ \\
\hline 9 & $\begin{array}{l}\text { Medan } \\
\text { High Court } \\
\text { Decision } \\
\text { Number } 30 \\
\text { / Pid.sus- } \\
\text { Anak / } \\
2018 \text { / PT } \\
\text { MDN } \\
\text { It was } \\
\text { decided on } \\
\text { September } \\
\text { 14, 2018 }\end{array}$ & $\begin{array}{l}\text { Perpetrator: } \\
\text { FS als FM; } \\
15 / 19 \\
\text { February } \\
2003 \\
\text { Victim: DK, }\end{array}$ & $\begin{array}{l}\text { Article } 332 \\
\text { paragraph } \\
\text { (1) of the } \\
\text { Indonesian } \\
\text { Criminal } \\
\text { Code Jo Law } \\
\text { RI No. } 11 \text { of } \\
2012 \\
\text { concerning } \\
\text { the system of } \\
\text { juvenile } \\
\text { justice, and } \\
\text { the } \\
\text { provisions of } \\
\text { the law } \\
\text { concerned }\end{array}$ & 1. & $\begin{array}{l}\text { Receive an appeal } \\
\text { from Legal } \\
\text { Counsel; } \\
\text { Strengthening the } \\
\text { decision of the } \\
\text { Medan District } \\
\text { Court on } 20 \\
\text { August } 2018 \\
\text { Number } 49 \text { / Pid. } \\
\text { Sus-Anak / } 2018 \text { / } \\
\text { PN MDN, which } \\
\text { is appealed; } \\
\text { Order the } \\
\text { perpetrators to } \\
\text { remain detained; } \\
\text { Imposing court } \\
\text { fees to the Actors } \\
\text { in the two court } \\
\text { levels, which is } \\
\text { appealed at IDR } \\
2,500 \text { (two }\end{array}$ \\
\hline
\end{tabular}




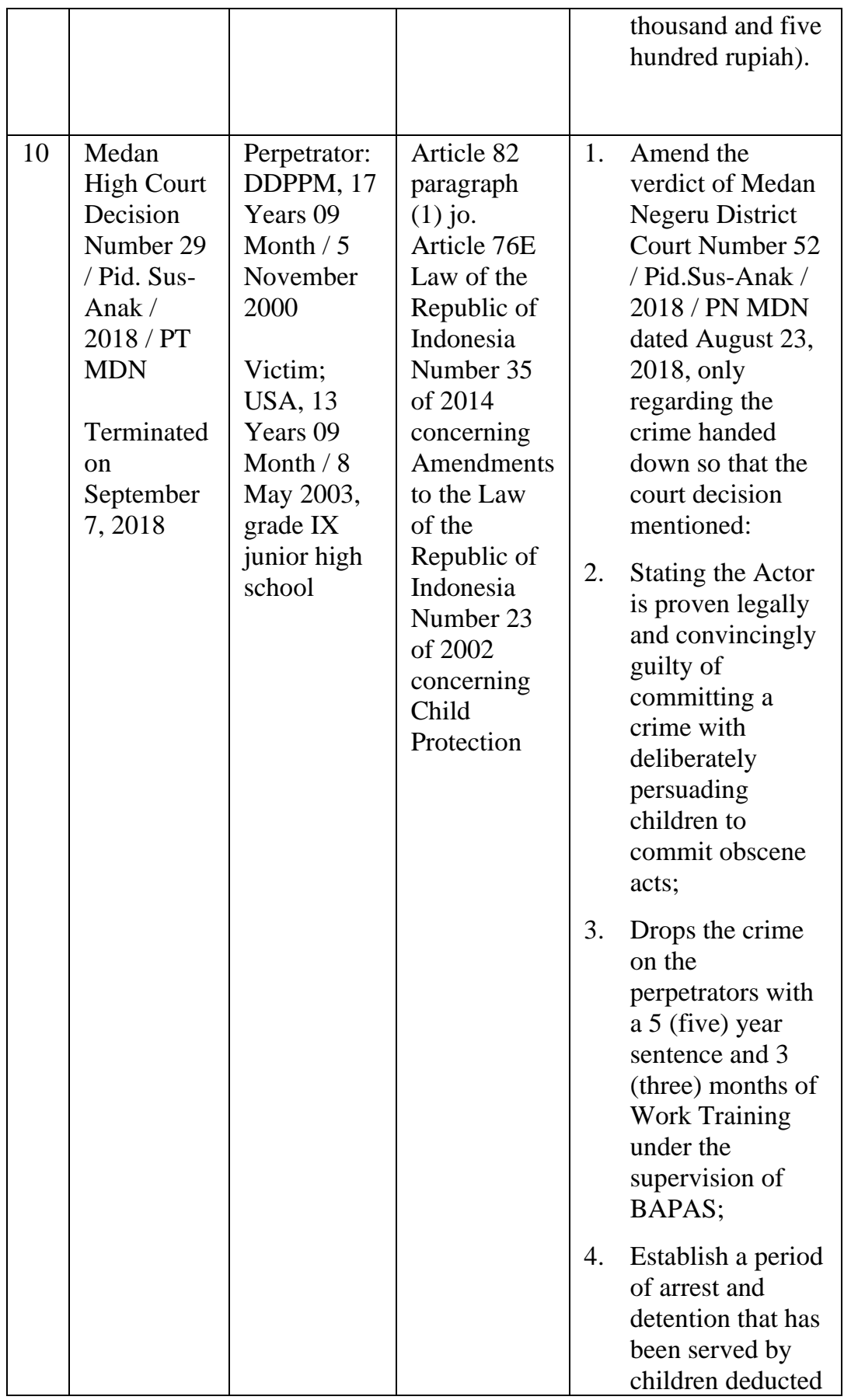




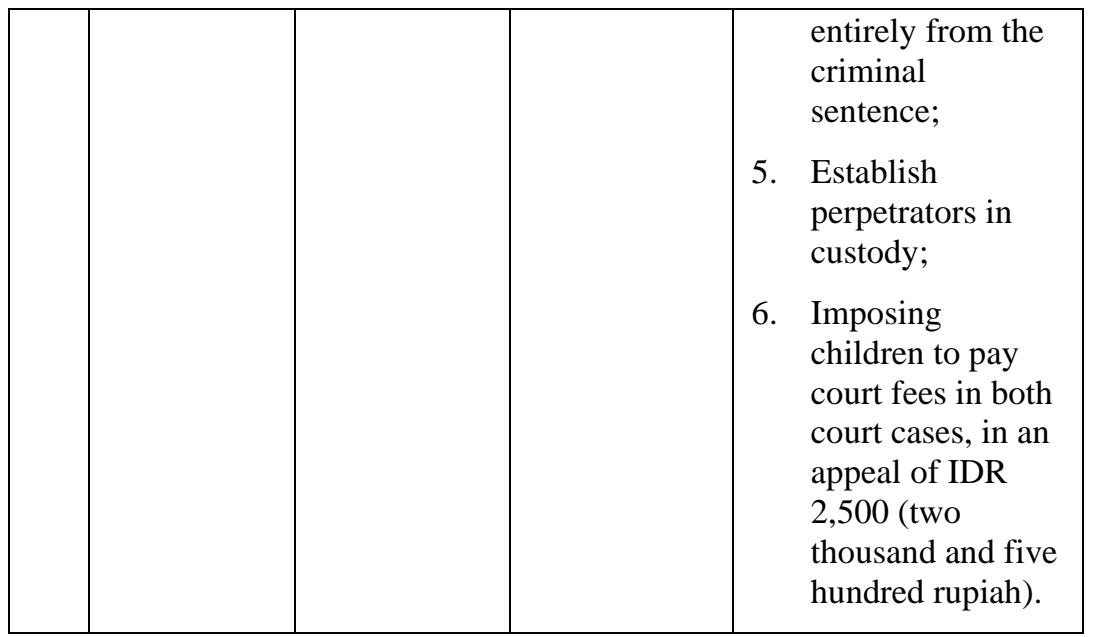

In this study, the application of the CRC for child victims of sexual violence as a legislative measure referred to in Articles 4, 19 and 34, CRC can be seen in the decisions of the District and High Courts in Table 3 above. As can be seen from the table, the national criminal law still applies to criminal offences against children who are victims of sexual violence. Namely, Article 332 paragraph (1) being guilty of abduction shall be punished; first, by a maximum imprisonment of 7 years, any person who carries off a woman under age without the will of her parents or guardians but with her consent, with intent to ensure himself of her possession within or outside marriage.

Article 332 which was used in Court Decision Number 49 / Pid.Sus-Anak / 2018 / PN.Mdn shows that the Law Enforcers especially Judges still see the criminal acts-sexual violation which happened on children as an ordinary crime. In actual fact, the judge must consider the criminal act as a special situation due to the fact that the victim is a child. This certainly violates the fulfilment of children's rights which are the obligations of a State party such as Indonesia. In the context of the CRC, a child does not have sexual consent or permission for any kind of sexual activity he/she does.

Since the court's decision involves children under the age of 18 (whether the offender or the victim), this research is even more 
important. ${ }^{21}$ In fact, this fact has been recognized by the Committee on the Rights of the Child, which involves the definition of child sexual abuse committed by another child to a child. ${ }^{22}$ These 10 court decisions show several interesting points relating to the term sexual violence refered to Article 19 and 34 (a) of CRC. According to Article 4 of the $\mathrm{CRC}$, this court decision is a manifestation of the legislative measures taken by the Indonesian government in fulfilment of child rights based on CRC. Furthermore, Article 19 of the CRC only mentions sexual abuse, the General Comment adds an explanation of the concept of Sexual Harassment and Exploitation. Sexual harassment and Exploitation include the inducement or coercion of a child to engage in unlawful or psychologically dangerous sexual activities. Meanwhile, Article 34 of the CRC mentions Sexual abuse \& sexual exploitation as the encouragement or coercion of a child to engage in unlawful sexual activity.

In referring to article 34 paragraph (1), the inducement or coercion of a child to engage in any unlawful sexual activity is a crime. The entire verdict should refer to the same decision, which states that the act that occurs is an act of unlawful sexual activity when referring to Article 7 paragraph 1 of the Marriage Law in UU No 1/1974 which regulates the minimum age of marriage for men is 19 years while for women are 16 years. All cases which analysed involved victims who are 13-15 years old. Some of the sexual activities include:

(a) kissing either the cheek, forehead or lips,

(b) hugging,

(c) touching the victim's breast,

(d) sodomy

(e) inserting a finger into the victim's genitals, and

(f) commits physical violence.

Now, Indonesia has the Law of the Republic of Indonesia Number 16 of 2019 concerning Amendments to Law Number 1 of 1974 concerning

21 Elimination of child labour, protection of children and young persons, Law on Child Protection, no 23 article 1 (2002).

22 Ben Mathews and Delphine Collin-Vézina, 'Child Sexual Abuse: Toward a Conceptual Model and Definition', Trauma, Violence, and Abuse, 20.2 (2019), 131-48 <https://doi.org/10.1177/1524838017738726>. 
Marriage as a follow-up to the decision of the Constitutional Court of the Republic of Indonesia which has issued Constitutional Court Decision Number 22 / PUU- XV / 2017 concerning ordering legislators a maximum period of 3 (three) years to make amendments to Law 1 of 1974 concerning Marriage related to age discrimination for women to marry, namely 16 years. Based on the Law of the Republic of Indonesia Number 16 of 2019 concerning Amendments to Law Number 1 of 1974, it is now stipulated that the legal age of marriage for bothwomen and men is at 19 years.

Another convicting matter which should be considered by judges as the element of the inducement or coercion of a child is statements as follows. There are some sentences which must be considered as the inducement or coercion:

(a) "I love you; I do not want to leave you and I will be responsible for anything" (Court Decision No. 86/Pid. Sus-Anak/2018 / PN Lbp);

(b) "... If you don't want to, I'll spread your " $a i b$ " disgrace with your friends at school and all your neighbours... "Court Decision Number 71 / Pid. Sus-Anak/2018/PN Lbp.

(c) "... you won't get pregnant."

(d) "I love you, later if there is anything I will be responsible" Court Decision No. 37 / Pid. Sus-Anak / 2018 / PN.Medan.

(e) Threat to spread the conversation or chat via mobile phone as stated in the Court Decision Number 30/Pid.SusAnak/2018/PN Mdn.

The judge considered that based on existing legal facts it was found that the element of "inducement" or "coercion" on the victim committed by the perpetrator to have sexual intercourse had been proven. This decision which is considered the statements in fitted with the definition of sexual abused of Committee on the Rights of the Child which mentions that many children experience sexual victimization which is not accompanied by physical force or restraint but which is nonetheless psychologically intrusive, exploitative, and traumatic. Sexual abuse comprises any sexual activities (1) imposed by an adult on a child, (2) when committed against a child by another child, (3) if the child 
offender is significantly older than the child victim or uses power, threat or other means of pressure. ${ }^{23}$

Furthermore, all elements which are available in Article 81 paragraph (1) of Law No. 35 of 2014 concerning Amendments to Law No. 23 of 2002 concerning Protection of Children which reads "Every person who violates the provisions referred to in Article 76D shall be sentenced to a maximum imprisonment of 5 (five) years and a maximum of 15 (fifteen) years and a maximum fine of IDR. $5,000,000,000.00$ (five billion rupiah) ". Whereas paragraph (2) reads "Criminal provisions referred to in paragraph (1) shall also apply to any person who intentionally commits deception, a series of lies, or entices the child to have intercourse with him or with others". Article 76 D referred to in Law No. 35 of 2014 concerning Amendments to Law No. 23 of 2002 concerning the Protection of Children which says that "Everyone is prohibited from committing violence or the threat of violence forcing children to have sexual intercourse with or with others".

According to Law No. 35 of 2014 concerning Amendments to Law No. 23 of 2002 concerning Child Protection shows that the recognized sexual violence is sexual intercourse meanwhile in the CRC in article 34 mentioning it as an unlawful sexual activity. The use of different terms between the CRC and the provisions of the Law set out in Law No. 35 of 2014 concerning Amendments to Law No. 23 of 2002 and used by Judges in the court decisions above do not fitted with the mandate of Article 34 of the CRC which states that the state party in particular must take appropriate, bilateral and multilateral measures to prevent sexual violence. Furthermore, there is a research finding on the use of the term sexual violence imposed on perpetrators who are relieved from types of violence that are classified as " sexual intercourse" which can be categorized as "rape". This includes obscene acts or even more ironic is when acts of unlawful sexual activity are expressed as acts that are unlawful but, "deserves to happen" as in Decision No. 52 / Pid. Sus-anak/2018/PN Lbp which stated the perpetrators were not proven legally and convincingly guilty of committing crimes as Article 81 paragraph (2) of Law No. 35 of 2014 concerning amendments to Law No. 23 of 2002 concerning the

23 Ibid. 
protection of children because the victim is the girlfriend of the perpetrator.

Using different a term to describe sexual violence include unlawful sexual activity between the CRC and the regulation in Law No. 35 of 2014 concerning amendments to Law No. 23 of 2002 concerning the protection of children, has caused perpetrators to be awarded with different sentences. The first difference is in the length of time for imprisonment that is awarded on the perpetrators which varies from two years to six years while at the High Court level, the punishment was decreased to 5 years. The second difference relates to the time for social work which must be undertaken by the perpetrator who is considered as a child, which varies from 2 months to up to 2 years.

\section{Restitution as the rights for child victims of sexual abuse}

The situation of the victims differs between one case to another. There is no decision that has considered the victim's rights for restitution as mentioned in Article 71D of Law No. 35 of 2014 concerning amendments to Law No. 23 of 2002 concerning the protection of children. Restitution is payment of compensation charged to the offender based on a court decision that has a permanent legal force for material and / or immaterial losses suffered by the victim or his heir. Restitution is a form of protection that can be enjoyed by victims of a material nature. ${ }^{24}$ It also ensures the recovery of material or physical and psychological losses to victims of child crime. ${ }^{25}$ This restitution has been regulated in the Government Regulation of the Republic of Indonesia Number 43 Year 2017 Regarding the Implementation of Restitution for Children Who Are Victims of Crime. In order to protect children who are sexual victims, the judges need to mention restitution

24 Sri Endah Wahyuningsih, 'Perlindungan Hukum Terhadap Anak Sebagai Korban Tindak Pidana Kesusilaan Dalam Hukum Pidana Positif Saat Ini', Jurnal Pembaharuan Hukum, $3.2 \quad$ (2016), 172 <https://doi.org/10.26532/jph.v3i2.1407>.

25 Josefhin Mareta, 'Penerapan Restorative Justice Melalui Pemenuhan Restitusi Pada Korban Tindak Pidana Anak', Jurnal LEGISLASI INDONESIA, 15.4 (2018), 287. 
in their decisions. ${ }^{26}$ Furthermore, Indonesia has a specific law which mention about restitution namely Law number 31/ 2014 concerning amendment to law number 13 of 2006 concerning protection of witness and victims.

The research results collected from two key discussions with the two groups; (a) law enforcement officials and (b) local government organizations (OPD) and child-related NGOs. This shows that it is related to the realization of the rights of children who are victims of international sexual violence, which is called restitution in international instruments, while Indonesian law calls it compensation, which shows that:

1. The judges make the decision based on the indictment; if it is a general crime then the Criminal Code is used. If it alludes to child protection, the Law on Child Protection is used. The facts of the verdict show that although the perpetrators and victims are children, there are still judges who use the general provisions stipulated in the Criminal Code.

2. The laws relating to issues of Restitution:

a. Law No. 11 of 2012 concerning the Criminal Justice System for Children (Sistem Peradilan Pidana Anak /SPPA) does not regulate the rights of victims, therefore there is a merger. Payment of compensation can be paid by the State and the Actor.

b. There is no rehabilitation for victims in the Criminal Procedure Code, but for the perpetrators. Rehabilitation was provided by a social institution, Lembaga Perlindungan Anak Sementara/LPAS.

c. Indonesia procedural legal system does not exist for judges providing protection either in the SPPA or the Criminal Procedure Code. PP no. 43 of 2017 concerning restitution.

26 Sri Endah Wahyuningsih, 'Perlindungan Hukum Terhadap Anak Sebagai Korban Tindak Pidana Kesusilaan Dalam Hukum Pidana Positif Saat Ini',

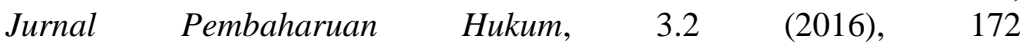
<https://doi.org/10.26532/jph.v3i2.1407>. 
d. In civil compensation, the conditions for the award of compensation is much clearer.

e. There is no measure for personal suffering, because there has not been a demand for such restitution, the judge also considers social sensitivities in the society as a measuring instrument when dealing with requests for restitutions;

f. Notes agreed by all participants of law enforcement show that there is the absolute use of the Criminal Procedure Code. Indonesia as a country that uses the Civil Law system must not leave the interpretation of the Law on the legal norms that have been set. This statement was emphasized by the Judge in the Focus Discussion exercise. He stated that in the implementation of the decision maker, the Judge was regularly limited in his decision making because he was bound by the Civil Law. When a judge is progressive, he deviates from his professionalism. ${ }^{27}$

3. Decisions which analysed which involve children as perpetrators and victims. For this reason, the Judge stated that he focused more on Law No. 11 of 2012 concerning SPPA which mandated the implementation of Diversity and Restorative Justice. This is based more on the reason that the regulation of the rights of victims of sexual violence in the SPPA Law and the Child Protection Act is very minimal;

4. Marriage is still an alternative choice as a cover for disgrace for the victim's family. For this reason, several of the judges' decisions offer reconciliation. Offering reconciliation between the perpetrator and the victim will also be able to ease the sentence of the perpetrator;

5. Law Enforcement officials (Judges, Prosecutors and Registrars) who attended the FGD stated that they did not know if there had been a Government Regulation governing restitution as the right

27 The focused group discussion for Law Enforcement with 6 Judges (District Court and High Court), 2 Public Prosecutors, and 1 Registrar, Medan, on May 14, 2019. 
of children victims of sexual violence. So far they only knew the restitution for victims of Trafficking in accordance with Law No. 21 of 2007 concerning the Elimination of Trafficking in Persons (Perlindungan Tindak Pidana Perdagangan Orang /PTPPO);

6. The police even explicitly stated that they were not aware of the existence of Government Regulations governing restitution, both Government Regulation Number 43 of 2017 concerning Implementation of Restitution for Children Who Become Victims of Crimes as mandated by Law No. 35 of 2014 concerning the First Amendment of Law No. 23 of 2002 concerning Protection Children or Government Regulation Number 7 of 2018 concerning Provision of Compensation, Restitution and Assistance to Victims as mandated by Law Number 13 of 2016 concerning Witness Protection.

\section{Conclusions}

This article demonstrates that none of the court decisions mentioned the rights of the victims to obtain restitution. The judges focused only to punish the perpetrators. Furthermore, the FGD also discovered that Judge(s) did not consider the victims' rights to restitution due to lack of information on the laws relating to restitution. It is ironic since the right is regulated under Government Regulation No. 43/2017 concerning Implementation of Restitution for Children Who Are Victims of Crime. It is recommended that the Government needs to train the Police Officers and Public Prosecutors on the laws relating to restitution and they should be more active in providing information restitution as a right for victims. It will help victims and their families claim for their rights. Last but not least, the police officer as the lead organ in law enforcement must prompt the CVSV and the victim and her family to apply for restitution as it is their right.

This research recommends that the Indonesian Government develop the use of the term sexual violence as is used in the CRC by continuing to make inducement, coercion and threat as an important element of sexual violence including unlawful sexual activities. Furthermore, legal officers including the enforcement officers such as the Police and also the Public Prosecutors should be more active in providing information concerning restitution as the right of victims which is regulated under Government Regulation No. 43 of 2017 
concerning Implementation on Restitution for Children who are Victims of Crime.

\section{Acknowledgment}

We would like to thank the Research and Service Institute of Universitas Sumatera Utara who supported the authors to implement research program through TALENTA Universitas Sumatera Utara research scheme of Fiscal Year 2019 based on the Rector Letter Number: 4167/UN5.1. R/PPM/2019. 